\title{
Description of the larva of Houardodiplosis rochae Tavares, 1925 (Diptera, Cecidomyiidae, Clinodiplosini) and new record of pseudoscorpions in galls
}

Valéria Cid Maia $^{1}$

\begin{abstract}
Aвstract. The larva of Houardodiplosis rochae Tavares, 1925 is described and illustrated for the first time. A new record of pseudoscorpion (Olpiidae) collected from galls is presented.
\end{abstract}

KeYworos. Cecidomyiidae; Diptera; Houardodiplosis; gall; pseudoscorpion.

\section{INTRODUCTION}

Houardodiplosis Tavares, 1925 (Cecidomyiidae, Clinodiplosini) is a monobasic genus described from Brazil. The only known species, $H$. rochae Tavares, 1925, causes bud swellings on Combretum leprosum Mart. (Combretaceae). TAVARES (1925) described the male, female and pupa. The type locality was not specifically stated, but the material was collected by Dias da Rocha, who regularly sent Tavares galls from the vicinity of Ceará (Brazil). The syntypes are presumed lost (GAGNÉ 1994). The larva of third instar is herein described for the first time based on material collected in Aracati (Ceará) by L. Frota (Universidade Federal do Ceará).

\section{MATERIALAND METHODS}

L. Frota collected samples of the galls in December, 1995 and sent them to the Laboratório de Diptera, Museu Nacional, Rio de Janeiro. Part of the sample was dissected under a stereomicroscope and the gall dwellers were removed and preserved first in $70 \%$ alcohol. The majority of the dissected galls were already empty, but some were still occupied by the mature larva of the gall maker and a single gall was occupied by a tritonymph of pseudoscorpion. The gall midge larvae were mounted on slides following the methodology of GAGNÉ (1994). The pseudoscorpion (a single specimen) was sent to Dr. Mark Harvey (Western Australia Museum, Australia), in order to be identified. The material was incorporated to the Diptera collection, MNRJ (part in 70\% alcohol and part as dried material).

RESULTS
Houardodiplosis rochae Tavares, 1925

(Figs. 1-3)

Houardodiplosis rochae Tavares, 1925: 113; Gagné, 1968: 23.27 (cat.); Gagné, 1994: 157.

Description of the mature larva. Color: yellow. Body length: $2.9 \mathrm{~mm}(\mathrm{~N}=2)$. Larva cylindrical, sligthly tapered at both ends (Fig. 1). Integument rough. Spatula with two anterior teeth and measuring $0.2 \mathrm{~mm}$ in length (N=2) (Fig. 2). Full complement of lateral papillae. Sternal and ventral papillae asetose. Three pairs of setose dorsal papillae. Pleural papillae setose. Hind spiracles situated near the distal margin of the eigth segment. Terminal segment with three pairs of corniform papillae (one pair smaller than the others) and one pair of setiform papillae (Fig. 3).

Examined material. BRAZIL, Ceará, Aracati, 1 larva, 17.XII.1995; 1 larva,03.XII.1995, L. Frota col. (MNRJ).

Comments. The tribe Clinodiplosini includes seven genera in the Neotropics, six of them endemic (GAGNÉ 1994). Among them, only the larva of Clinodiplosis spp., Latrophobia brasiliensis Rübsaamen, 1916 and Schismatodiplosis lantanae Rübsaamen, 1916 were described. The morphology of the larva of Houardodiplosis rochae confirms its position among the Clinodiplosini, being similar to the larvae of Clinodiplosis species.

Other dweller. Probably a Olpiolum sp. (Olpiidae, Pseudoscorpiones). The generic assignment is difficult to ascertain with a nymphal specimen (HARVEY, personal comunication).

This is the second record of a pseudoscorpion collected from galls in Brazil. MAIA (1999) recorded the presence of

1. Museu Nacional, Departamento de Entomologia. Quinta da Boa Vista, São Cristóvão, 20940-040 Rio de Janeiro - RJ, Brazil. E-mail: maiavcid@acd.ufrj.br 

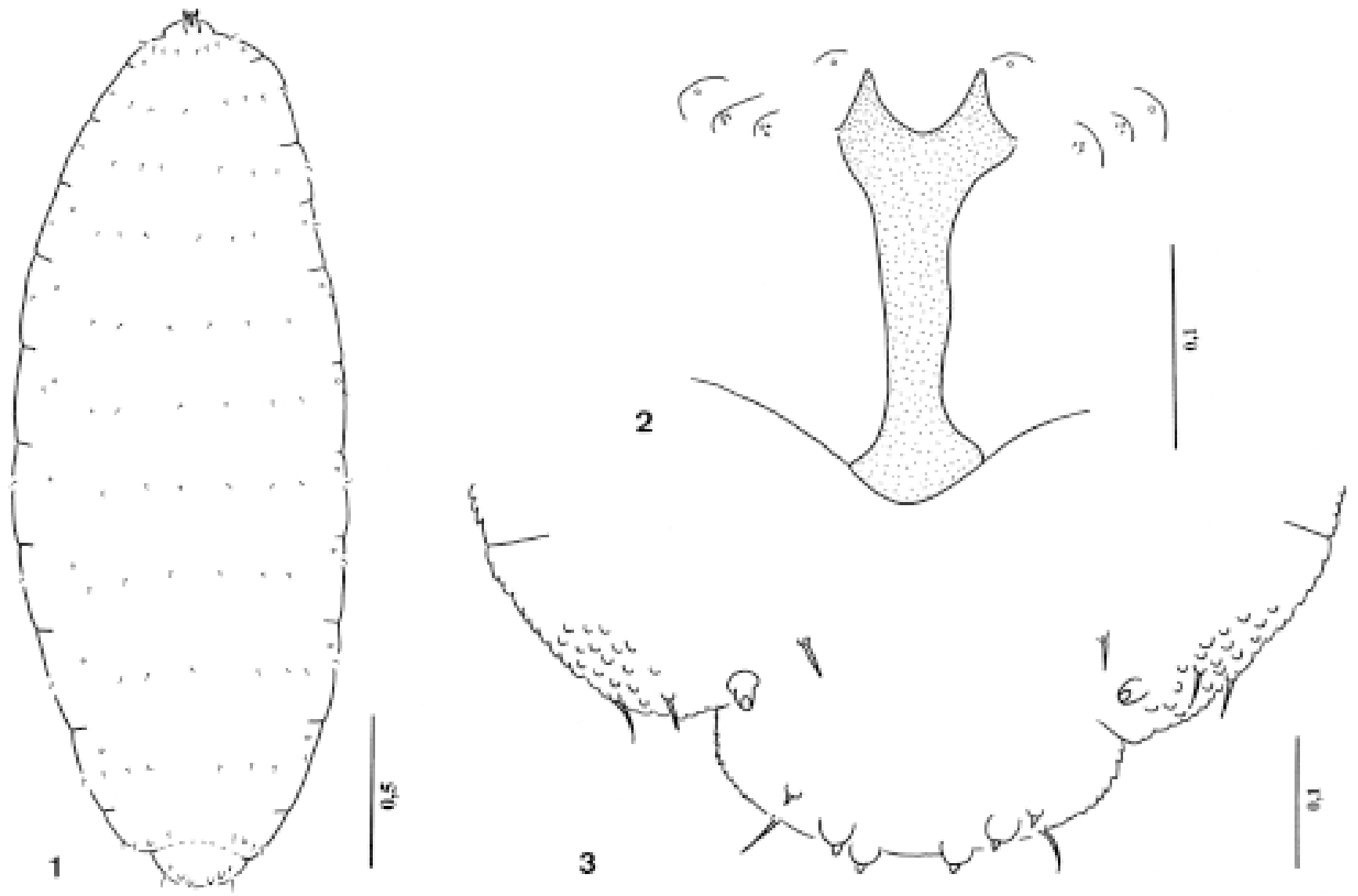

Figs. 1-3. Larva of Houardodiplosis rochae Tavares, 1925. 1, general aspect (dorsal view); 2, spatula and associated papillae (ventral view); 3, terminal segments (dorsal view). Scale bars in mm.

Novohorus sp. (Olpiidae) in galls of Stephomyia rotundifoliorum Maia, 1993 on Eugenia rotundidolia Casar (Myrtaceae). Nanolpium spp. (Pseudoscorpiones: Olpiidae) were recorded from moth galls on Stipagrostis sabulicola and S. cf. namaquensis (Poaceae) in southern Africa (Nanibia and Zimbabwe) (Judson \& HeurTault 1996).

Acknowledgments. I am grateful to L. Frota (Universidade Federal do Ceará) who kindly collected the galls; to Dr. Mark Harvey (Western Australia Museum, Australia), for the pseudoscorpion identification; to Dr. Márcia Couri (Museu Nacional, Rio de Janeiro) for her critical examination of the text and to Fundação de Amparo à Pesquisa do Estado do Rio de Janeiro ( E -26/151.714/1999) for the financial support.

\section{REFERENCES}

GaGNÉ, R. J. 1968. Family Cecidomyiidae, (23), p. 23.1-23.62. In: N. Papavero, (ed.). A Catalogue of the Diptera of the Americas South of the United States. São Paulo, Museu de Zoologia da Universidade de São Paulo.

Gagné, R. J. 1994. The Gall Midges of the Neotropical Region. Ithaca, Cornell University Press, $352 \mathrm{p}$.

Judson, M. L. I. \& J. HeuRTault. 1996. Nanolpium species (Garypoidea, Olpiidae) on grasses in southern Africa - a new niche for pseudoscorpions. Revue Suisse de Zoologie, vol. hors, série: 321326.

MaIA, V. C. 1999. Artrópodes associados às galhas de Cecidomyiidae (Diptera) em Eugenia rotundifolia (Myrtaceae) e Clusia lanceolata (Clusiaceae) no Brasil. Iheringia, Série Zoologia, 87: 75-79.

TAVARES, J. S. 1925. Nova contribuição para o conhecimento da Cecidologia Brazileira. Brotéria, Série Zoológica, 22: 5-48, pls. XI-XIX.

Received in 08.VIII.2001; accepted in 30.XI.2001. 